\title{
ADMINISTRATIVE ASPECTS OF A NEGATIVE INCOME TAX
}

\section{SHELDON S. COHEN $\dagger$}

In recent years, there has been growing discontent with the nation's welfare programs. The resulting discussions have produced a broad range of criticisms. It is said that present programs do not reach all of the poor; that benefits are too small for many of those who receive them; that eligibility tests are demeaning and incentives for self-betterment are stifled, with the result.that too many people are "going on relief"; that family instability is encouraged, and that administration of the programs is inefficient and lacks uniformity. While agreement on the validity and importance of all these criticisms is lacking, there is nevertheless widespread interest in a reappraisal of our social welfare efforts.

Present programs encompass a broad range of activities and benefits, including those aimed at providing money income through jobs and job training (Office of Economic Opportunity programs, for example), insurance against money income loss (social security and unemployment insurance), income in kind (housing, medical benefits, food stamps, and so forth), indirect benefits such as special tax provisions for the aged, and direct public assistance to various categories of the poorthe aged, the disabled, the blind, and dependent children.

Certainly a sizeable effort has been made to alleviate poverty-and much has been accomplished-but few are satisfied with the results. Research and discussions on the subject have brought forth a variety of proposals for income maintenance. One of these, the proposal for a negative income tax, has sparked considerable interest in wide ranging segments of our society. It is, of course, an idea of particular interest to me because it has been proposed as an extension of the present tax system.

The term "negative income tax" was developed from the notion that an individual whose income is too low to allow him to use all his income tax exemptions and deductions should receive from the federal government a payment determined by application of a negative tax rate to the unused value of those exemptions and deductions. ${ }^{1}$ Subse-

† A.B. 1950, J.D. 1952, George Washington University. Former Commissioner of Internal Revenue. Member, District of Columbia Bar.

1 This concept assumes that there is a rational basis in the amount of exemptions allowed. There is considerable doubt concerning the validity of that assumption. The deductions and exemptions are merely another method of adjusting tax rates. 
quently, the concept has become less specific. Several different proposals have been advanced, all of which would provide a guaranteed basic income, the amount of which would gradually fall to zero at less than a dollar-for-dollar rate as other income rose. The amount of the benefit would depend exclusively on the beneficiary's financial status and the size of his family. The administrative framework would be similar to that now used for the positive tax system.

Proponents of such plans argue that a negative income tax would have several advantages in comparison to the existing welfare system. It would reduce or avoid the social stigma associated with many of the present programs. By providing objective national eligibility and benefit standards, it would end the personalized and diverse eligibility tests that are often objectionable, and might slow the migration of the poor to the overburdened cities. Self-betterment would be encouraged by removal of the disincentive effects of the generally prevailing requirement that benefits be reduced on a dollar-for-dollar basis when other income rises. Standardization and centralization of program operations would permit streamlined and efficient administration. ${ }^{2}$ Implicit in all of the proposals is the assumption that the Internal Revenue Service could efficiently administer a negative tax with only minimal incremental costs.

Despite the current and widespread interest in a negative income tax, there is no consensus on the specific form it should take, how it should be related to other welfare programs, or even whether or not it is desirable. There are conflicting views on the basic approaches to welfare. Should the major emphasis be on redistribution of money income, or should the poor be given income in kind? Do work-incentive and social considerations require different programs for different categories of the poor, or should there be a single program with benefits solely dependent on financial status? In addition, there is the pragmatic question what changes in present welfare programs would be politically acceptable to the nation as well as the Congress. Would it be more feasible to accomplish needed changes through modification of existing programs or by creation of a new program? ${ }^{3}$

2 Some recent developments indicate a movement within the existing system in the direction of some of these objectives. The Supreme Court has invalidated residence requirements and the "man-in-the-house" rule, and the Department of Health, Education, and Welfare has published a proposed regulation that would, beginning July 1, 1969, eliminate the wholesale investigation of welfare recipients that is now common in nearly all states. Also, the Social Security amendments of 1967 provide for a reduction in benefits at a less than one-for-one rate when the recipient's earnings increase.

3 For a thoughtful discussion of these questions by the former Secretary of Health, Education and Welfare, see Brandon, Wilbur Cohen Talks About .. Poverty and How to Fight It, N.Y. Times, June 23, 1968, \&6 (Magazine), at 10. 
While these are important and interesting questions, which deserve further thought and research, the question to which my comments will be directed is a much narrower one. If a negative income tax is desirable, what administrative considerations should those who are to design a practical, workable program take into account? I am particularly concerned with the following problems.

1. Proposed plans seem to try too hard for conceptual perfection. For example, it is commonly proposed that imputed rent on owner-occupied dwellings, and the value of food grown and consumed on a farm, be included in the measurement of the negative tax beneficiary's nonallowance income. While the inclusion of such items is obviously of importance in terms of equity, there are troublesome administrative implications.

2. Most proposals explicitly or implicitly assume that a large part (or all) of the work now performed by welfare workers would not be necessary with a negative income tax. I believe that taxpayer assistance would be a major administrative cost item, and that a sizeable reporting verification program would be necessary. Proposed definitions of income and reporting units (families) and the lack of record-keeping experience of many negative taxpayers would make audits difficult. And in view of the financial status of negative tax beneficiaries, the recoupment of overpayments would present difficult problems.

3. All of the proposals assume that the use of computers would allow a very simple system for processing claims and paying benefits. In my opinion, the data processing job would be large and complex. In some ways, it would be more difficult than the IRS's present processing operations.

4. It is commonly assumed that a negative income tax could be administered by the IRS with very little incremental cost. Although the Service might administer such a program as efficiently or perhaps more efficiently than other agencies, to do so would require a considerable amount of extra work, involving more than a token expansion of present activities.

My intention in this article is not to argue the pros and cons of a negative income tax. Nor do I argue that administrative considerations should be overriding. But I would urge proponents of a negative tax to recognize some potential problems and to be willing to accept reasonable compromises in certain cases where conceptual perfection conflicts with administrative practicality. The discussion that follows assumes that a negative tax system would be administered by the Internal Revenue Service. This is not, of course, a necessary 
assumption, but the problems discussed would not be peculiar to an IRS administration.

\section{Professor Tobin's Proposal 4}

Professor Tobin has proposed a very comprehensive plan, one particularly suitable as a point of reference for my comments because it gives more than usual attention to operating details of the proposed system and to points the authors have referred to as "sticky technical problems." In brief, Professor Tobin's plan would operate as follows. Any family unit could claim a negative income tax allowance payment, the amount of which would be related to size of family; but those receiving an allowance would pay a special tax of, say, 50 per cent of their gross nonallowance income. Thus, as a family's income rose, the net benefit from the negative tax system after tax on other income would fall until a breakeven point was reached. For example, under one of the schedules presented in the article, a family of four would receive a basic allowance of $\$ 2600$ per year and its gross income would be taxed at a rate of 50 per cent. The family's net allowance or benefit would be $\$ 2600$ if its other income was zero. With an increase in nonallowance income, the net benefit would fall by half the amount of income. Thus, an income breakeven point would be reached at $\$ 5200$, where the tax would equal the $\$ 2600$ allowance. ${ }^{5}$

In order to avoid a "notch" problem, whereby a change from the negative to the positive system could result in a sharp increase in the tax paid, the authors propose that the family or tax unit be allowed to remain under the negative tax system until its disposable income is exactly the same under the positive and negative income tax. Continuing the example above, a change from the negative to the positive system at an income of $\$ 5201$ would require a positive tax of $\$ 32$. In other words, $\$ 1$ additional earned income would cause a reduction in disposable income of $\$ 31$. Therefore, under the proposed plan, the taxpayer would elect to stay under the negative system until his tax-

4 Since the various negative tax proposals have much in common, at least from an administrative viewpoint, it is not necessary that I comment on all of them. Instead, most of my comments will be directly related to a proposal presented in the Yale Law Journal by Professors James Tobin, Joseph A. Pechman, and Peter M. Mieszkowski. Tobin, Pechman, \& Mieszkowski, Is a Negative Income Tax Practical?, 77 YALE L.J. 1 (1967) [hereinafter cited as Tobin]. For convenience, the authors' proposal will be referred to as Professor Tobin's proposal.

In addition, I will conclude this paper with a brief discussion of a less comprehensive plan.

For a recent statutory proposal, see Comment, A Model Negative Income Tax Statute, 78 YALE L.J. 269 (1968).

5 Fifty per cent of $\$ 5200$, or $\$ 2600$. 
breakeven income level was reached, namely when his nonallowance income reached $\$ 6144 .^{6}$

The authors also propose that, in recognition of the welfare objective, a negative tax system should include an offsetting tax on wealth as well as on income.

This very brief summary of Professor Tobin's proposal will be supplemented as the discussion progresses by further description of features having particular administrative significance. Included will be the definition of the tax unit, as well as determination of income subject to the negative tax and benefit payments.

\section{Some Basic Conditions to Be Recognized}

Although the existing positive tax system is hardly a model of administrative simplicity, it does have some outstanding features that were designed to make the system administratively feasible. The Internal Revenue's job and the taxpayer's burden of compliance have been greatly simplified by the withholding of tax on wages, by the standard deduction, and-at least to some extent-by the definition of income. While these simplifying features are less than perfect in terms of equity, they are widely accepted because of their overwhelming administrative importance to both the IRS and the taxpayer. I doubt, for example, that any serious student of taxes would argue that there should be no standard deduction.

The point is that similar, less than perfect compromises would be imperative in a negative tax system. First, we must recognize that the persons covered by a negative income tax would include the less literate part of the population. Second, persons at or below the poverty level are likely to have little financial management experience. Third, many will be receiving small bits of income from jobs where there is little or no recordkeeping to provide a basis for the taxpayer's income reporting or an audit track for an enforcement program. Fourth, accurate income imputations and valuations of payments in kind (which would be required by some negative tax proposals) are seldom simple. Finally, it seems appropriate to recognize that there may be a significant difference in the social and ethical values of negative and positive taxpayers. For example, most positive taxpayers regard being caught for income tax cheating as a stigma to be avoided. This feeling may be less prevalent among people who have suffered the indignities of poverty. What these points mean, in my opinion, is that designers of a negative tax system must sharply limit their expectations of the income reporting that could or would be done by negative taxpayers.

${ }^{6}$ As a matter of convenience, this discussion ignores the temporary $10 \%$ surcharge. 
Before turning to specific administrative problems, there is one other general point that demands serious attention. What kind of enforcement program would be desirable for a negative tax system? An enforcement program requires enforceable provisions. Since published comments have only touched upon this point, I shall proceed with the assumption that a rather vigorous enforcement program would be required, at least one that would roughly parallel positive tax enforcement. This seems a reasonable assumption in terms of what might be acceptable to the public, what might be required by the Congress, and what would be equitable for all concerned.

It is conceivable that some might argue that a strong enforcement program would thwart one of the major attractions of the negative tax, namely, avoidance of the indignities of means tests required by present welfare programs. But if enforcement is limited to an impersonal financial factfinding procedure similar to that employed for the positive system this point cannot be regarded as valid.

\section{Definition of the Negative Income Tax Base?}

The definition of income for negative tax purposes is extremely important. It would be a major determinant of the net benefit to be received by a family; it would have a direct bearing on the equity of the system; and it would to a large extent determine the enforceability of the system's provisions and the taxpayers' ability to report properly.

Professor Tobin defines income to include all items in the positive tax base plus many items excluded in whole or in part from the positive tax. A broad definition is, of course, in harmony with welfare and equity objectives. However, from the administrative and compliance viewpoints, there are questions that must be raised regarding such a broad definition. Without trying to cover all possible problems, let us look at those involved with some of the specific items proposed for inclusion in the negative tax base.

1. Tax-exempt interest, realized capital gains, scholarships and fellowships in excess of tuition, income from minerals net of cost depletion rather than percentage depletion, and dividend and sick pay exclusions probably would not present significant problems. These items not only have established meanings, but they are generally payments related to accounting systems that can supply information to the

7 Although the mechanics for utilizing taxpayer income data vary among the negative tax proposals that have been made, most of the proposals would, like Professor Tobin's, require the use of a broad definition of gross income. Therefore, the following comments are relevant to other proposals, even though income may not be used as a negative tax "base" per se. 
taxpayer and the IRS. Furthermore, I would expect these items to be relatively infrequent among those taxpayers we are considering; in addition, they are small in amount. Should they prove significant, some information reporting might be desirable.

2. Although the treatment of children's income is not spelled out in Professor Tobin's proposal, it deserves comment. Records of children's income are undoubtedly very incomplete, and the reporting of such income would be almost impossible to enforce. Therefore, from an administrative viewpoint, children's income should be omitted from consideration except where it is subject to tax withholding or information reporting under current tax law. The object would be to avoid the obvious enforcement problems that would be associated with income sources such as lawnmowing and babysitting, where recordkeeping is practically nonexistent and there is no convenient basis for the establishment of systematic accounting procedures. At least some minimum level of such income should be ignored.

3. The value of food grown and consumed "on the farm" is a real potential trouble maker. While the equity argument for including such "income" in the negative tax base is obvious, procedures for compliance and enforcement would be extraordinarily difficult. Professor Tobin suggests that "[i]t should be possible to settle on a flat per capita amount for each state (if not for each region) to be added to the money income of farmers for this purpose." 8

At first blush this may seem to be a reasonable compromise between equity and administrative considerations, but I believe the proposal deserves a critical second look. First, who is a "farmer"? Of the total food grown and consumed by potential negative taxpayers, what proportion is accounted for by persons, such as backyard gardeners, hired farm laborers, and rural residents, who do not operate farms in a business sense? Second, would the amount of income imputed for home consumption by negative taxpayer farmers be significant? It is my impression that people actually in the business of farming generally specialize in certain crops that are largely produced by mechanized methods. Growth of a substantial amount of food for home consumption generally requires a high use of manual labor, which few farmers are prepared to supply. Also perhaps of some significance is the fact that the Department of Agriculture's estimates of the value of home consumption by all farmers indicate a rapidly declining level. Administrative considerations suggest that the imputed value of home consumption by farmers should be omitted from the negative tax

8 Tobin $12-13$. 
base unless and until it can be authoritatively shown that (a) the amount of such consumption would be really significant for negative taxpayers, and (b) equitable and practicable enforcement is possible. With present information, or lack of information, the only feasible solutions seem to be an "honor system" for inclusion of such income in the tax base, an inequitable standard imputation, or complete omission.

4. Imputed net rent for owner-occupied dwellings would present similar problems. Tobin says that calculation of the amount is "admittedly difficult," but states that "most persons should be able to estimate the market value of their homes by correcting their property tax assessments for the generally known rate of underassessment in their locality." 9 Rate of return on the market value would be set at an arbitrary but reasonable level. Mortgage interest would be deductible from income, or, alternatively, the set rate of return could be applied to the owner's equity.

This suggestion for handling the imputation presents at least two problems. First, IRS experience with positive taxpayers indicates that a high percentage of negative taxpayers would be unable to properly make the required calculations. ${ }^{10}$ Second, the suggested methodology would not produce very accurate results.

Property tax assessments are notoriously lacking in uniformity. One student of the property tax, Dick Netzer, summarizes this point as follows: " $[\mathrm{T}]$ here is conclusive evidence that, within most individual assessment jurisdictions, even the most common, least heterogeneous properties-single-family nonfarm houses-are assessed at widely varying fractions of market value." 11 Netzer cites U.S. Bureau of Census assessment-sales ratio data for 1961 for 1356 selected local areas. In 70 per cent of the areas, the average deviation from the median assessment ratio in that jurisdiction for single-family nonfarm houses was 20 per cent or more. In 19 per cent of the areas, the average deviation was 40 per cent or more. ${ }^{12}$ These data indicate that rent imputations based on assessed values would be very inaccurate and substantial inequities in the relative treatment of homeowning negative taxpayers would result.

What then would be a better procedure for handling the imputed rent situation? Unfortunately, I do not have the answer, but I urge

9 Tobin 12.

10 They might satisfactorily supply on standard forms the basic data needed, if the tax assessor and mortgagee are cooperative. The subject of calculations is discussed at pp. 692-93 infra.

11 D. Netzer, Economics of the Property Tax 174 (1966).

12 Id. 177. 
serious consideration of two possibilities. First, an expert appraisal system, perhaps through an extension of the FHA's functions, could be used to minimize the problem of inaccurate appraisals. Second, if the cost of a special appraisal system should be found prohibitive, consideration should be given to omission of imputed rent from the negative tax base. Since the negative tax is proposed as a welfare program with built-in incentives for participants to better their economic positions through their own efforts, exemption of imputed rent might not seriously detract from the conceptual soundness of the plan. It is possible that long range social and economic considerations might justify preferential treatment of certain forms of wealth in limited amounts. If dwelling investment by a taxpayer should be relatively large, it could fall under the tax on wealth discussed below. ${ }^{13}$

5. Professor Tobin proposes that the value of meals and lodging provided by employers be included in the tax base. In lieu of this, income for the negative tax system might be defined to include payments in kind taxable under current income tax laws. This would seem largely to accomplish the equity objective for inclusion of non-money income, while at the same time significantly simplifying the administrative aspects involved in the interrelationship of the positive and negative tax systems. As will be pointed out later in the discussion, ${ }^{14}$ many taxpayers may be expected to fall near the breaking point of the two systems and all reasonable steps should be taken to minimize the complexity of the determination of their proper status.

6. It is proposed that some government transfer payments be included in the negative tax base. Inclusion of these payments should not present administrative problems if the present payer information reporting system were extended to such payments. Since the information returns would generally be prepared by government agencies utilizing modern computer technology, the identity data and other information that they contain would be highly reliable and would contribute substantially to the effectiveness and efficiency of enforcement efforts.

7. A tax on wealth, although not as high as the tax on income, is also contemplated. This capital tax might be a flat percentage, say 10 per cent, of the family's net worth above a fixed exemption. Alternatively, property income might be excluded from taxable income and a higher tax rate applied to capital, say 5 per cent on net worth up to

13 See pp. 686-87 infra.

14 See p. 689 infra. 
the exemption level mentioned above, and 15 per cent above that point. Tobin suggests that valuations for net worth determinations should be on a current market basis and that "where market values are not available, they should be approximated by expert appraisers." 15

The second proposal for a capital tax implies a special government appraisal program, which would be very comprehensive and very expensive, assuming taxpayer arranged private appraisals are not envisaged by the authors. It seems to me that the equity values involved do not justify such a complex procedure, and it would certainly be unreasonable to expect all negative taxpayers to prepare net worth statements without assistance.

Returning to the first proposal-a tax on net worth in excess of an exemption-the administrative and compliance burdens could be kept within reason if the exemption were not set at too low a level. If the exemption were set at, say, $\$ 20,000$, most poor people would not have to concern themselves with net worth statements, and those who would be concerned should be more capable of handling the matter. However, the problem of obtaining expert appraisals would remain, although its limited occurrence should permit the development of practicable procedures for handling it.

\section{Determination of Negative Tax Benefits}

Professor Tobin describes two methods of handling benefit payments, and apparently considers them equally satisfactory. One system contemplates automatic payment of the full basic allowance: all families who have not excluded themselves from the program would be sent a check at weekly or biweekly intervals, and the first $M$ dollars of their earnings would be subject to withholding at the negative tax rate. ${ }^{16}$ Tax on income not subject to withholding would have to be paid through a quarterly declaration. An adjustment for any overpayments or underpayments would be made by an annual tax return to be filed no later than the following April 15th. The taxpayer could elect to withdraw from the program at any time.

Under the second method, declarations by benefit claimants, any family that believes itself eligible for benefits would submit a declaration. According to Professor Tobin, "[t]he declaration might be a simple post-card form requiring information only on family composition, expected income for the year, income in the prior quarter, and (if the

15 Tobin 18.

${ }^{16} M$ is the taxpayer's annual tax-breakeven-point income divided by the number of pay periods in the year. 
proposed offsetting tax on wealth were adopted) net worth." 17 The government would estimate net benefits, taking into account tax to be withheld under the regular withholding system, which would not be changed in any way. Benefit checks would be mailed weekly or biweekly. A new declaration would be filed whenever a family found that its income was exceeding or falling short of expectations. A final accounting, including an adjustment for overpayment or underpayment, would be made with a final annual return.

Professor Tobin feels that the major advantage of the first method is that taxpayers would be less likely to abuse the system by obtaining overpayments. An important advantage of the declaration method is said to be avoidance of any change in the withholding system. Before commenting on the specific proposals described above, I think it would be helpful to make some general comments on determination and method of benefit payments.

Eligibility determinations. For the reasons already stated, reporting demands on negative taxpayers should be minimized. Return forms, whether declarations or final returns, should be as simple as possible. Calculations by the taxpayer should be avoided. He should only supply information necessary for the IRS's determination of eligibility for benefits and the amount of benefits.

But a determination by the IRS would still require fairly detailed information on family composition, the amount and types of income received, and the distribution of income among family members. Such detail would be particularly important for people who are near the positive-negative tax-breakeven points. The tax-breakeven-point income for a family of given size varies with the type of income (for example, whether it is income which would be subject to the positive tax, i.e., adjusted gross income (AGI)) and the distribution of income among family members. Assume, for example, a family of four that would file under the positive tax system a joint return covering all members. Under Professor Tobin's high-benefit, 50 per cent rate plan, the family's tax-breakeven income would be $\$ 6144$, if all of the income were AGI type. On the other hand, if the income were all nonAGI type, the breakeven point would be $\$ 5200$. Combinations of AGI and non-AGI types of income would result in breakeven points anywhere between these two levels depending on the proportions of the two types. The distribution of income among family members and the number of returns that would be filed under the positive system would also affect the level of the breakeven point. 
The example above and the illustrations presented in Professor Tobin's article assume use of the standard deduction for positive tax calculations. This is a convenient way to explain the basic idea for dovetailing the two tax systems, but it is, of course, an oversimplification. With breakeven points as high as those proposed by Professor Tobin, many taxpayers who would itemize deductions on positive tax returns would be involved in the negative tax. Their tax-breakeven income levels would be lower than those of taxpayers who claim standard deductions. For example, under the 50 per cent negative rate plan, a family of four with all AGI-type income and itemized deductions of $\$ 1000$ would have a tax-breakeven point of $\$ 5959$, rather than the $\$ 6144$ level obtained with the standard deduction.

Obviously, then, for many tax entities a determination whether they should be under the positive or negative system would be a complex matter, and it seems reasonable to assume that there would be a sizeable number of families whose income would be near the breakeven points.

The over-and underpayment problem. Another point of general relevance to the handling of benefit payments is the need to minimize intrayear over- and underpayments. Underpayment of benefits would, obviously, conflict with the basic purpose of a negative tax program. Overpayments should be avoided because of the difficulty of making corrective adjustments. The economic position and probable lack of money management experience of a large proportion of negative tax beneficiaries make it improbable that overpayments by the government would be voluntarily repaid at the time of the annual accounting. Since collection procedures normally employed for positive tax deficiencies might be regarded as too harsh for negative taxpayers (and in many cases they would be ineffective), the most feasible collection method would be an offsetting reduction in future benefits. ${ }^{18}$ In view of program objectives, this is, of course, an additional reason for trying to avoid overpayments.

Evaluation of Professor Tobin's alternatives. Going back now to the two methods of payment proposed by Professor Tobin, which is better from an administrative point of view? It seems to me that the plan providing for automatic payment of full benefits has several serious faults. I do not think all positive taxpayers (who would vastly outnumber negative taxpayers) and all employers should have to bear the burden of waiving the negative tax. If full basic allowance payments and negative tax withholding were limited to those who requested coverage, rather than those who did not waive coverage, the overall 
burden would be greatly reduced. Without the automatic feature of the plan, there would be cases where benefits would be paid but negative withholding (because of failures in communications or cheating) would not be put into effect when it should. But this would be more palatable than the greater volume of inappropriate and unwanted benefits and negative tax withholdings that would result from the proposed automatic system.

The plan providing for payment of full benefits (with or without the automatic feature) would, of course, impose an additional significant burden on the IRS and employers: a dual withholding system. The extent of this additional burden would, in part, depend on the number of people who receive negative benefit payments although their income is above the level where such payments are appropriate. If negative tax waivers were necessary, the number inappropriately covered might be quite large because of failures to file waivers. A significant number of overpayment adjustments would have to be made even if benefits were paid only on request, because some people would have higher earnings than they had anticipated. At any rate, Professor Tobin has not explained how tax withholding would be handled in cases where earnings exceed negative tax withholding levels.

To illustrate this point, consider the following example. Assume a family of two with a basic allowance of $\$ 1600$, a negative tax rate of fifty per cent, and a tax-breakeven point of $\$ 3,868$. Assume the allowance would be paid in twenty-four installments of $\$ 66.67$. Withholding would be at the fifty per cent rate on earnings up to $\$ 322.33$ per month ( $\$ 3868$ per year). Now, the question is how withholding would be handled if earnings in a given month were higher than $\$ 322.33$. I do not know what the authors of the proposal have in mind. If the positive tax withholding tables were used for the earnings in excess of $\$ 322.33$, underwithholding would result. One way the situation might be handled is as follows: when the employee's wages are higher than $\$ 322.33$, the employer would withhold the full positive tax withholding amount on total wages plus an additional $\$ 66.67$, the amount needed to offset the negative allowance payment. If this method were followed, employers would have to accommodate three tax witholding procedures-regular positive tax withholding, negative tax withholding, and positive tax plus benefit withholding.

Another problem with this method of paying benefits is that it assumes that the taxpayer can determine whether he should be under the negative system. It seems to me that the number who could not make a proper determination would be large enough to raise considerable doubt about the practicality of the plan. 
The method also assumes that the IRS would have a master file of information on entity composition for negative tax purposes. Since it seems logical that negative tax entities not be defined in terms of the present positive tax reporting rules, and since a large number of the potential negative taxpayers are not on present income tax rolls at all, it is obvious that the IRS does not now have the information necessary for the required master file. Such a file could come only from special reporting by taxpayers, and frequent updating would be necessary. Also, employers do not have the information needed to determine taxbreakeven income values, which would have to be known to place the proposed limits on negative withholding. Even the major claimed advantage of the automatic, full-benefit plan, minimization of overpayments, may be more apparent than real. To the extent that income not subject to withholding is undeclared, underdeclared, or the tax on such income is not timely paid, overpayment of benefits will result. Consequently, the plan appears particularly unsatisfactory for a new program.

With some modifications, the method requiring declarations by claimants seems to have much to recommend it. I would suggest that the regular withholding system be changed to the extent of having no withholding on wages of negative tax allowance recipients, that is, those who have a net allowance payment after deduction of the negative tax. As soon as the IRS determines that an allowance is in order, the employer could be notified to stop withholding. This would be a very small imposition on employers and needless cross-transfers of money would be avoided. The wages of taxpayers whose benefit from the negative tax system is a reduction in taxes (those with an income level between their income breakeven point and their tax-breakeven point) could be subject to withholding in the regular manner; and on the basis of their declaration, the IRS could pay them the amount of their tax reduction, subject, of course, to a final accounting.

Another part of the declaration plan, however, could present administrative problems. As a check on the reasonableness of the claimant's estimate of income, it is proposed that such estimates be compared with income information already available from prior years and prior declarations. There is no explanation of how the results of such checks would be used, but the implication is that claims based on income estimates that are lower than previous levels (or estimates) by some tolerance amount would not be honored. If this is what the authors have in mind, then it would seem to follow that, for such cases, a prepayment "audit" or investigation would be made. Experience might prove that this check on declarations would be necessary, but I would 
hope that it could be avoided through the quarterly adjustment method described later. Annual audits of financial records will be difficult enough, and "audits" of estimates of future income would be impossible.

The information on the claimant's declaration would have to be complete enough to permit the IRS to determine whether the negative tax is appropriate and, if so, to compute net benefits. Since the initial benefit calculations would be based on expected income, deductions, and family composition at the declaration date, over- and underpayments would undoubtedly result. In order to reduce the problem of accumulating large adjustment amounts, the negative taxpayer should be required to file a quarterly or semiannual redeclaration, which would report any changes in anticipated income or family composition. Benefit payments would then be revised accordingly.

\section{The Nature and Complexity of the Administrative Job}

The number of people or families that would be involved in a negative tax system would be determined by income eligibility rules, tax unit definitions, the extent to which beneficiaries are "recruited," and economic conditions of the time. A report published by the Brookings Institution in 1967 contains an estimate of the number of beneficaries for a negative income tax plan which appears to be the same, or almost the same, as Professor Tobin's low-benefit, $33 \frac{1}{3}$ per cent plan. The report indicates that in 1964 about twenty-four million families (about ninety million people) would have been eligible for coverage by such a plan. ${ }^{19}$ If a negative tax program is established, it might cover fewer people, at least initially, but the number covered is only one item involved in an appreciation of the administrative implications of negative tax proposals.

Although cost measurements of the administrative job are beyond the scope of this paper, the points discussed below provide an indication of the complexity and magnitude of negative tax administration.

Taxpayer assistance. The IRS now has an assistance program for positive taxpayers, but it is very unlike the program that would be needed for a negative tax. Present assistance is in response to requests, and generally involves questions related to fairly simple tax returns. People with complicated returns-particularly high income taxpayers-usually have private tax advisors. As a result, the positive taxpayer assistance program, although adequate to the need, is relatively small in size and scope.

19 C. Green, Negative Taxes and the Poverty Problem 194 (1967). 
Experience with other programs involving benefit payments suggests that a sizeable effort would be needed just to acquaint potential beneficiaries with the program and obtain applicants for negative tax benefits. It is probable that those in need would be the least likely to apply on their own initiative. The basic objective of the program would require recruitment of beneficiaries. This would be particularly true in the early years of a program, but to some extent I would expect a continuing need for recruitment. The poverty universe is not static, and like other government programs, the scope and operation of a negative tax system is likely to be modified as a result of experience and changing social attitudes.

Negative taxpayers can be expected to require substantial assistance in the preparation of declarations and annual returns. The extent of such assistance would be directly affected by the complexity of program provisions. Even if provisions were relatively simple, omitting such requirements as income imputations and valuations of payments in kind, many negative taxpayers would still need help; and, unlike the positive tax program, the need for assistance would be a year-round matter, including a heavy volume or correspondence regarding eligibility, benefit adjustments, changes in employment, and so forth.

I believe it is relevant and significant that about fifty-two per cent of the persons filing positive tax returns, with income under $\$ 10,000$ and no business income, receive assistance on their tax returns, and that almost seventy per cent of these pay for the assistance. The need for assistance by negative taxpayers would undoubtedly be greater, and creation of a new "assistance industry" to meet this need is hardly compatible with welfare objectives. The IRS should at least be in a position to meet requests for help, and serious consideration should be given to the possibility that assistance should be required for initial applications.

If assistance on initial applications were mandatory rather than voluntary, the total cost of assistance would, of course, be greater; but administrative benefits would also be realized. There should be a smaller incidence both of deliberate and of unintentional taxpayer errors, and identification data such as names and social security numbers would be more reliable. This would expedite the processing of claims and to some extent reduce the need for subsequent enforcement efforts.

The probable size and nature of the assistance program would be such that it could not be handled as a simple expansion of the duties of present taxpayer assistance employees. The number of employees and job qualification requirements would be quite different. 
Recordkeeping. The recordkeeping job would be complex as well as voluminous. In addition, in order to minimize delays in benefit payments and at the same time minimize incorrect payments, there would be an unusual need for rapid decision-making and updating of the information on which decisions would be based.

Two major factors would contribute to the complexity of records and their use. First, the information requirements would be quite different from those of the positive tax system. The phasing together of the two systems, however, would require an integration, or at least cross-referencing, of the two. The interrelationship would be particularly difficult to handle because of the proposed differences in definition of reporting units. It is proposed that a negative tax unit be defined to include the members of a "family" who pool their incomes and who are dependent upon such pooled resources. A single negative "family" might consist of individuals who would, if their incomes were higher, file one or several positive tax returns.

The second factor that would give rise to complexity in the accounting job would be the dynamic nature of taxpayer circumstances over time. Many changes should be expected that would require modification of records and benefit payments. For example, the income of a tax family might increase, requiring a downward adjustment in benefits or a switch to the positive system ; ${ }^{20}$ its income might fall; the distribution of income among family members or a change in type of income might change the positive-negative breakeven point; the composition of a unit might change as a result of births, deaths, marriages, etc.; addresses might change; two negative units might merge; or one unit might split into two.

Welfare, equity, and enforcement considerations would seem to require that benefit payments be adjusted at intervals during the year rather than be accumulated for an annual accounting. Even with provisions for adjustments during the year, annual corrections would still be needed because of errors in income estimates, unanticipated deductions, and the like. For all adjustments, there would be an urgency that does not exist in relation to present tax accounting. As a result, the negative tax record file should be expected to be large, extremely active, and complex. The demands of the job probably would exceed any present data processing program.

Professor Tobin's article describes fluctuating income situations that might lead some to require income averaging by certain negative

20 In one study of the poor, it was found that $19 \%$ of the families with money income below $\$ 3000$ in one year had incomes higher than $\$ 3000$ in the following year. See Econonic Report of the President, January 1965, at 164. 
taxpayers. I would hope that his conclusion that such averaging would not be desirable will ultimately prevail. If averaging were required, the data file would have to extend over a period of several years, and determining who should average and calculating the averages would add tremendously to the administrative burden.

Enforcement activities. The size and nature of a negative tax audit program would, in large part, depend on points discussed earlierthe items of income to be included in the negative tax base, the complexity of the information reporting required of benefit claimants, the amount of taxpayer assistance provided, and the rules regarding membership in a tax unit. For reasons already stated, we should expect a much higher error rate for negative taxpayers than for positive taxpayers. If the negative tax system's designers feel that it is essential that imputed rent, payments in kind, value of farm products consumed at home, and income from sources without business records be taken into account, then they must expect a very large and expensive audit program-one with a much higher auditor-taxpayer ratio than that for the positive system. For this reason, I again urge that these particularly complicating features be reconsidered with full recognition of administrative problems.

Under the negative tax plan proposed by Professor Tobin, some of the low-income taxpayers now covered by the positive system would move to the negative system where a relatively high tax rate (331/3 to 50 per cent) would apply, and where tax withholding would no longer minimize errors. As a result, the number of errors and their dollar significance would cause these taxpayers to constitute a greater enforcement problem than they do at present.

In addition, as stated earlier, a program with integrity would require a fairly extensive audit of taxpayers having little or no income. This is particularly true in relation to family or tax unit membership. The proposed dual system of reporting unit rules would undoubtedly create confusion and reporting errors; and the tax (or benefit) impact of such errors would, of course, be much greater for a negative than for a positive taxpayer.

Aside from these questions, a negative tax audit program might be influenced by the social and ethical values mentioned early in this paper. Despite the administrative advantages of tax withholding and the standard deduction, there are still ways to cheat under the present tax system. A very small percentage of tax returns is audited, yet compliance with the tax laws is remarkably high. The combination of a strong puritan ethic and the possibility of being selected for a return audit causes most taxpayers to "voluntarily" report their income. 
If a substantial portion of negative taxpayers should not be similarly motivated, the per-taxpayer enforcement cost of a negative tax could be many times that of the present positive tax.

The collection of overpaid benefits should be accomplished in most cases by adjustment of future benefits. Consequently, the administrative burden would fall largely on the data processing organization. Under the positive tax system, collection procedures are as follows. A statement of tax due is mailed to the taxpayer requesting that payment be made within a specified period. If payment is not duly made, a delinquent account is established and the taxpayer is personally contacted in an effort to obtain payment. If the taxpayer still neglects or refuses to pay, lien, levy, or seizure procedures are employed. These collection techniques do not appear to be satisfactory for recovery of overpayments of negative tax benefits. Many people would regard them as too harsh for poor people. Furthermore, they would be ineffective in many cases because of the financial status of the individual. But the administrative burden of recovering overpayments could be minimized by offsets against future benefit payments. If a taxpayer moved up into the positive system in the year following one in which negative benefits were overpaid, I assume collection of the overpayment through regular positive tax procedure would be in order and would be provided for in appropriate legislation.

If the quarterly declaration system were conscientiously used by negative taxpayers so that intrayear adjustments in benefit payments could be made expeditiously, it should be possible to keep individual amounts to be collected-that is, cumulative overpayments-at low levels. As a result, deducting overpayments of past benefits from future benefits should not have too harsh an impact on most beneficiaries. The procedure would be somewhat similar to the current practice of deducting unpaid liabilities from refunds due under the positive tax system. However, an offset of significant size under a negative system probably should be spread over several payment periods.

It should be recognized, however, that the occurrence of a large number of overpayments would be unavoidable. The probable volume suggests that, from an administrative viewpoint, the provisions for waiver of recovery of overpayments of social security and veterans' benefits would be undesirable for use in connection with a negative tax. ${ }^{21}$ For those programs, no recovery is made from any person who is without fault if recovery would defeat the purpose of benefits otherwise authorized or would be against equity and good conscience. Such a

21 See Social Security Act $\S 204$ (b), 42 U.S.C. $\$ 404$ (b) (Supp. III, 1968); 38 U.S.C. $\$ 3102$ (a) (1964) (veterans' benefits). 
waiver rule implies burdensome investigative procedures which would take into account the financial position of the individual, the complexity of the circumstances involved, and the individual's capacity to realize that he is being overpaid. ${ }^{22}$

In view of the large number of overpayments that would probably occur with a negative tax program, I think recovery through adjustment of future benefits should be a routine and automatic procedure. Some reasonable limitation could be made on the amount which could be deducted from a single payment. This is in line with my earlier statement on the need for a strong enforcement program and my concern for administrative feasibility. It does not run counter to Professor Tobin's proposal. Even with the proposed recoupment procedure, it is likely that a sizeable amount of write-off on uncollectable accounts would be necessary.

A full discussion of a negative tax enforcement program would require a more detailed development of operating procedures, which involve more than administrative questions. For example, if there were an overpayment of benefits to a negative tax family in a given year and the family moved up to the positive system, with two positive returns, in the following year, who would be responsible for returning the overpayment to the Government? The answer to this question and many others not even identified here will also help determine the magnitude and complexity of an enforcement program. For example, the area of sanctions deserves thorough study. The objectives of a negative tax, its reporting requirements, and the characteristics of the people who would be involved, suggest that penalties and procedures should be quite different from those of the positive tax system. As an illustration, I seriously doubt that fraudulent amounts involved in a negative income tax, even though widespread, would individually be large enough to sustain a good record of jury convictions. The most effective penalty for chronic offenders might be denial of future benefits.

\section{A Less Comprehensive Proposal}

Since Professor Tobin's negative income tax proposal would provide higher benefits and cover more people than most other plans that have been advanced, a brief discussion of a less comprehensive proposal is in order. One relatively modest plan that has been advanced may be summarized as follows. If a family's income were less than the aggregate value of its positive tax exemptions and its minimum standard

22 These considerations are specifically called for in the case of social security benefits by regulations under 42 U.S.C. $\$ 404$ (b) (Supp. III, 1968). See 20 C.F.R. \$\$ 404.507-09 (1968). 
deduction, it would be entitled to receive from the government a payment equal to 50 per cent of the unused value of exemptions and deductions. For example, the value of exemptions and the minimum standard deduction for a family of four is $\$ 3000$, and if the family had no income, its negative tax payment would be $\$ 1500$, i.e., 50 per cent of $\$ 3000$. If nonallowance income amounted to $\$ 2000$, the benefit would be $\$ 500$, derived as 50 per cent of the difference between $\$ 3000$ and $\$ 2000$.

From an administrative viewpoint, this plan differs from Professor Tobin's proposal in several ways. First, the number of beneficiaries would, of course, be smaller-amounting to perhaps 21 million individuals in 6 million households. Second, the people covered probably would constitute a more stable group (heavily weighted with the hardcore unemployed), with fewer and smaller fluctuations in income and less movement in and out of the positive tax area. Third, since those covered would not be taxable under the positive tax system, the two systems would not have to be phased together to avoid the "notch" problem described under Professor Tobin's proposal. Fourth, since benefits would be limited to people with very low incomes, the number and variety of income items to be accounted for would be smaller. Finally, benefit recipients would probably be less literate and less experienced in recordkeeping, making mandatory assistance on initial applications highly desirable.

Except for these differences, the administrative implications are very similar to those of Professor Tobin's plan, particularly in regard to the definitions of income and reporting unit or family. Differences in program operations would be largely a matter of scale. Coordination of the positive and negative systems would be less complex but still necessary.

\section{Negative Tax Administration in Perspective}

The discussion above is intended to emphasize the need for proper recognition of the administrative aspects of negative income taxation in future thinking and planning. The successful operation of a negative tax plan would in no small part depend upon a reasonable blend of conceptual soundness and administrative practicality. Desired objectives will not be accomplished if the beneficiaries of the program are unable to cope with the complexities of its provisions, or the administrative agency-which will always be faced with sharp limitations on resources-is unable to see that the provisions are carried out. 